\title{
TRANSLATION AND INTERPRETATION STUDIES
}

DOI https://doi.org/10.30525/978-9934-588-90-7-57

\section{ПРОЗА ГРИГОРА ТЮТЮННИКА В ПЕРЕКЛАДІ УГОРСЬКОЮ МОВОЮ}

\author{
Балла Е. Ю. \\ кандидат філологічних наук, дочент, \\ дочент кафедри украӥнської літератури \\ Ужггородський начіональний університет \\ м. Ужгород, Украӥна, \\ дочент кафедри украӥнської мови та культури \\ Ніредьгазький університет \\ м. Ніредьгаза, Угорщина
}

Творчість Григора Тютюнника, талановитого прозаїка-шістдесятника, без сумніву, належить до вершинних здобутків українського художнього слова. Він, за спостереженням Л. Тарнашинської, «явив українській літературі, що перебувала у пошуках формотворчих засобів, складну простоту життєвої автентики такої потужної переконливості, що відразу зарекомендував себе письменником стефаниківської глибини, подібних якому на той час не знаходилося» [3, с. 394].

Проза Гр. Тютюнника була й залишається в полі наукового зору багатьох літературознавців. Це засвідчують 3 десяток захищених дисертацій, численні монографічні дослідження, сотні наукових статей, матеріали наукових форумів. Крізь призму багатьох аспектів, таким чином, твори письменника вже розглядалися науковцями. Що ж до питання про поширення творів Гр. Тютюнника на зарубіжних теренах, зокрема в угорськомовній інтерпретації, то воно практично не висвітлювалося в працях тютюнникознавців, що зумовлює актуальність нашої наукової розвідки. Мета дослідження - представити угорські переклади творів письменника, зосередивши увагу на хронології наближення їх до угорського читача, на джерелах, де вони публікувалися, та постатях інтерпретаторів цих прозових текстів.

Угорський читач уперше отримав можливість долучитися до художнього світу Григора Тютюнника в 1968 році, коли вийшла друком антологія «Ukrán elbeszélők» («Українські оповідачі»), де було представлено переклад його новели «Сито, сито...», здійснений Д. Радо. 
Частково про цю публікацію йдеться в іншому нашому дослідженні $[1$, c.139-140], у якому наголошується на тому, що найголовнішим i, напевно, найскладнішим завданням перекладача $\epsilon$ відтворити етноментальний та мовний колорит прози українського автора, ту специфіку його індивідуального авторського почерку, що дала підстави Л. Тарнашинській слушно охарактеризувати митця як «одного з найвдумливіших майстрів [...] художньої етнопсихології» [3, с. 14]. Практично в усіх оглянутих нами перекладах інтерпретаторам вдається оприявнити стрижневі риси неореалістичної поетики Гр. Тютюнника.

Найбільше в галузі трансляції художнього слова українського митцяшістдесятника в угорський культурно-естетичний простір зробив Пал Мішлеї, якого А. Гедєш назвала «україністом з-над Дунаю», окресливши його колосальний внесок у популяризацію української літератури в Угорщині [2]. I справді, завдяки П. Мішлеї, який навчався в Київському університеті, деякий час викладав там угорську мову та літературу i відповідно опанував українську мову, були представлені в угорському літературно-художньому дискурсі твори П. Загребельного, О. Гончара, Ю. Щербака, Вал. Шевчука, Р. Іваничука.

Саме П. Мішлеї спричинився до того, що спадщина класика української прози Гр. Тютюнника постала перед угорським реципієнтом у своїх найдовершеніших зразках - новелах «Оддавали Катрю», «Три плачі над Степаном», «Три зозулі з поклоном», «Крайнебо».

Перший перекладений П. Мішлеї твір Гр. Тютюнника - новела «Три плачі над Степаном» - з'явився друком у журналі «Szovjet irodalom» («Радянська література») у 1978 році. Цього ж року в журналі «Szputnik» («Супутник») вийшло оповідання «Оддавали Катрю» («Kátyát férjhez adják»).

Наступна публікація творів митця в журналі «Szovjet irodalom» за 1986 рік супроводжується перекладом фрагментів статті Олеся Гончара «Живописець правди» («Az igazság festője»), одне 3 тверджень якої П. Мішлеї перекладає так: «Hrihir Tyutyunnik elbeszélései az ukrán széppróza gyöngyszemei közé tartoznak» («Оповідання Григора Тютюнника належать до перлин української художньої прози») [5, с. 75]. Такими «перлинами» $\epsilon$, зокрема, й представлені тут ліричні, емоційно та психологічно наснажені Тютюнникові тексти - новела «Три зозулі 3 поклоном» та новелістичний цикл «Крайнебо». Поетичні засоби вираження, щільність письма, що забезпечується майстерним використанням художніх деталей, занурення в психологію персонажівоповідачів - усе це проглядається і в угорських варіантах цих творів. Неореалістична поетика з вкрапленнями імпресіонізму, настроєвість та 
ліризм, виняткове мовне багатство П. Мішлеї переважно вдалося відобразити засобами угорського художнього слова.

Важчим завданням було відтворення елементів потужної фольклорної поетики, точніше відфольклорного символізму, притаманного новелам Гр. Тютюнника. Свідченням цього $є$ те, що в перекладі двох новел, у назвах яких фігурує числова символіка фольклорної генези, - «Три плачі над Степаном» та «Три зозулі з поклоном» - інтерпретатор вдається до модифікації заголовку. Перша новела має назву «Sirató Sztepan halálára», що дослівно перекладається як «голосіння (плач) над Степаном», а «Три зозулі 3 поклоном» опубліковані під назвою «Mondd meg néki, kakkumadár...», що означає «Скажи їй, зозуле». Відповідно трансформовано і фрагмент «останнього листа від батька», де згадується символічний образ трьох зозуль: «Szonya, menj el hozzá, s azt üzenem, amit a zinykovi vásáron a vak bandolás énekelt: «Mondd meg néki, kakkumadár...»; csak hát nem tudom, átrepüli-e az én madaram a határtalan Szibériát, vagy röptében fagy meg» $[9$, c.80]. В оригіналі ж маємо так: «Соню, сходи до неї і скажи, що я послав ій, як співав на ярмарках Зіньківських бандуристочка сліпенький, послав три зозулі з поклоном, та не знаю, чи перелетять вони Сибір неісходиму, а чи впадуть од морозу» [4, с.284]. У перекладі назва $\epsilon$ цитатою з пісні, яку співав сліпий бандурист, у першоджерелі ж це символ, що асоціативно постає з почутої колись пісні.

Предметом іншомовної інтерпретації стала не лише новелістика Гр. Тютюнника. В угорському варіанті вийшла друком повість «Облога», що разом із кількома зразками повістевої прози 70-х років склала антологію «Ismerősöm, az oroszlán. Hét ukrán kisregény» («Мій знайомий лев. Сім українських повістей») (1977) [7]. Цей переклад також реалізував П. Мішлеї.

У 1987 році побачила світ угорськомовна версія повісті Гр. Тютюнника «Климко», яка увійшла до антології художніх текстів [8], перекладених Іштваном Петровацом - талановитим угорським письменником, майстром художнього перекладу, головним редактором видавництва «Móra Ferenc Ifjusági Könyvkiadó». Прикметно, що назва цього видання «Halál egy marék sóért», що перекладається «Смерть за дрібку солі», - це асоціація з сюжетними перипетіями, що становлять розв'язку перекладеної повісті Гр. Тютюнника. В одному з інтерв'ю I. Петровац ділиться своїми враженнями про роботу над окремими текстами, зокрема й повістю «Климко», називаючи цю працю «Хвилинами, наповненими радістю» («ӧrömteli perceim») [6, с. 148].

Отже, можемо констатувати, що проза Гр. Тютюнника у кількох своїх найпоказовіших зразках та в майстерній інтерпретації була представлена 
угорському читачеві і за життя письменника, і після його смерті завдяки зусиллям таких перекладачів та упорядників, як П. Мішлеї, Д. Радо, I. Петровац. Їхня праця повинна бути належно оцінена в сучасному літературознавстві, тому перспективу подальших наукових пошуків убачаємо в глибшому аналізі мовно-стилістичних та поетикальних особливостей угорських перекладів текстів митця.

\section{Література:}

1. Балла Е. Мала проза українських письменників-шістдесятників у перекладі угорською мовою. Науковий вісник Ужгородського університету. Серія Філологія. Вип. 2 (42). Ужгород, 2019. С. 137-143.

2. Гедєш А. Україніст 3-над Дунаю. Всесвіт. 1986. № 4. С. 162-164.

3. Тарнашинська Л. Біль - як четверте мистецтво: «спостережний пункт» прози Григора Тютюнника. Украӥнське шістдесятниитво: профілі на тлі покоління: (історико-літературний та поетикальний аспекти). К.: Смолоскип, 2010. С. 390-439.

4. Тютюнник Г. М. Твори. Книга I: Оповідання / Упоряд. А. Шевченко. Передм. О. Гончара. К.: Молодь, 1984. 328 с.

5. Honcsar Olesz. Az igazság festője. Szovjet irodalom. 1986. 7. szám. C.75-76. URL: https://adtplus.arcanum.hu/hu/view/SzovjetIrodalom 1986_07-09 (дата звернення: 30.08.2020).

6. Petrovácz I. «Először az asztalfióknak fordítok». Szergej Fagyejev interjúja. Szovjet irodalom. 1986. 10. szám. C. 146-148. URL: https://adtplus.arcanum.hu/hu/view/SzovjetIrodalom_1986_10-12 (дата звернення: 24.10.2020).

7. Tyutyunnyik H. Az ugar. Ismerösöm, az oroszlán. Hét ukrán kisregény / Vál. Karig S. Budapest: Európa Könyvkiadó, 1977. C. 5-114.

8. Tyutyunnyik H. Klimko. Halál egy marék sóért. Ukrán kisprózák. Szerkesztő Szakonyi Csilla. Budapest-Uzsgorod: Móra Ferenc Ifjusági Könyvkiadó - Kárpáti Könyvkiadó, 1987. C. 5-84.

9. Tyutyunnyik H. «Mondd meg néki, kakkumadár...»; Látóhatár. Szovjet irodalom. 1986. 7. szám. C. 77-86. URL: https://adtplus.arcanum.hu/hu/view/ SzovjetIrodalom_1986_07-09 (дата звернення: 30.08.2020).

10. Tyutyunnyik H. Sirató Sztepan halálára. Szovjet irodalom. 1978. 3. szám. C. 87-92. URL: https://adtplus.arcanum.hu/hu/view/ SzovjetIrodalom_ 1978_01-03 (дата звернення: 30.08.2020).

11. Tyutyunnyik H. Szita, szita. Ukrán elbeszélők / Vál. Karig S. Budapest: Europa, 1968. C. 507-513. 